\title{
PERAN PAKLOBUTRAZOL TERHADAP PERTUMBUHAN TANAMAN DAN FISIOLOGI LATEKS BEBERAPA KLON KARET
}

\author{
The Role of Paclobutrazol Toward Plant Growth and Latex Physiology \\ on Some Rubber Clones
}

Try KORYATI ${ }^{1 *}$ dan Radite TISTAMA ${ }^{2}$

${ }^{1)}$ Departemen Agroteknologi

Fakultas Pertanian Universitas Amir Hamzah Medan Jalan Pancing Pasar V Barat Medan Estate Kenangan Baru

Percut Sei Tuan Deli Serdang 20219 Sumatera Utara

*Email: trykoryati@gmail.com

${ }^{2)}$ Pusat Penelitian Karet

Jalan Raya Palembang - Pangkalan Balai KM 29

Sembawa Banyuasin 30953 Sumatera Selatan

Diterima : 14 Juli 2020 / Disetujui : 21 Desember 2020

\begin{abstract}
This research was aimed to determine plant growth, anatomy, and physiological characteristics of latex produced from several rubber clones at the initial tapping with the use of paclobutrazol as plant growth regulator. Paclobutrazol an organic compound is a growth inhibitor which can inhibit stem lengthening and increase stem diameter, thus shorten immature period of rubber. The study was carried out at Karang Inong Plantation PT Perkebunan Nusantara I, East Aceh. The research was arranged based on two factors of Nested Design, namely rubber clone factor such as $K_{1}=P B 260, K_{2}=P B 330, K_{3}=P B$ $340, K_{4}=I R R \quad 107$ and $K_{5}=\operatorname{IRR} 5$. Furthermore the second factor was paclobutrazol factors, namely; $P_{o}=$ control (without paclobutrazol), $P_{1}=(500 \mathrm{ppm}$ paclobutrazol applied through the soil) and $P_{2}$ $=(500 \mathrm{ppm}$ paclobutrazol applied on the leaves). Application of paclobutrazol through soil was given twice, first was at the time of research and second was at 6 months after treatment, while application of paclobutrazol through leaf surface spraying was given as ten times starting from the implementation of the study at intervals of once a month. Observations were made at the beginning of the study (28 months) and 46 months in the field. The results showed that clone and paclobutrazol affected significantly plant growth, latex production and physiological characteristics of latex. Application paclobutrazol through soil suppressed plant height, but increased stem girth, bark
\end{abstract}

thickness and latex vessel diameter. Interaction between the treatment of clones and paclobutrazol on the highest latex production $(22.81 \mathrm{~g} / \mathrm{t} / \mathrm{t})$ and $\mathrm{DRC}(36.47 \%)$ were found in clone $P B 340$ without paclobutrazol $\left(K_{3} P_{o}\right)$. Meanwhile the highest in organic phosphate $(4.92 \mathrm{mM})$ and Thiol $(0.38 \mathrm{mM})$ were found in the treatment of $K_{4} P_{1}$ and the lowest plugging index was found in the $K_{3} P_{2}(18.71 \%)$. The results of the research was regarded as one of the solutions to shorthen immature period of rubber, because it could inhibit plant height and accelerate stem girth growth.

Keywords: Bark anatomy; clones; latex physiology; paclobutrazol; plant growth

\section{Abstrak}

Tujuan penelitian ini untuk mengetahui pertumbuhan tanaman, anatomi dan karakter fisiologi lateks beberapa klon karet pada penyadapan awal dengan penggunaan zat pengatur tumbuh paklobutrazol. Paklobutrazol merupakan zat penghambat pertumbuhan yaitu suatu senyawa organik yang mampu menghambat pemanjangan batang dan dapat meningkatkan diameter batang, sehingga memperpendek tanaman belum menghasilkan. Penelitian dilaksanakan di Kebun Karang Inong PT Perkebunan Nusantara I, Aceh Timur dan PT Perkebunan Nusantara III. Penelitian disusun 
berdasarkan Rancangan Tersarang (Nested Design) dua faktor, yaitu faktor klon karet dengan lima taraf yaitu $\mathrm{K}_{1}=\mathrm{PB} 260, \mathrm{~K}_{2}=\mathrm{PB}$ $330 \mathrm{~K}_{3}=\mathrm{PB} 340, \mathrm{~K}_{4}=$ IRR 107 dan $\mathrm{K}_{5}=$ IRR 5 dan faktor paklobutrazol dengan tiga taraf yaitu $\mathrm{P}_{0}=$ Kontrol (tanpa paklobutrazol), $\mathrm{P}_{1}=$ 500 ppm paklobutrazol melalui tanah dan $\mathrm{P}_{2}$ $=500 \mathrm{ppm}$ aplikasi paklobutrazol melalui daun. Aplikasi paklobutrazol melalui tanah diberikan hanya dua kali yaitu pada saat pelaksanaan penelitian dan enam bulan setelah perlakuan (BSP), sedangkan aplikasi paklobutrazol melalui penyemprotan permukaan daun diberikan sebanyak 10 kali mulai dari pelaksanaan penelitian dengan interval satu bulan sekali. Pengamatan dilakukan pada awal penelitian (umur 28 bulan) dan dilanjutkan pada umur 46 bulan di lapangan. Hasil penelitian menunjukkan bahwa respon masing-masing klon dan aplikasi paklobutrazol menunjukkan pengaruh yang berbeda terhadap parameter pertumbuhan tanaman, produksi lateks dan karakter fisiologi lateks. Aplikasi paklobutrazol melalui tanah nyata menekan pertambahan tinggi tanaman, tetapi dapat meningkatkan diameter batang, tebal kulit dan diameter pembuluh lateks. Interaksi antara perlakuan klon dan paklobutrazol terhadap parameter produksi tertinggi $(22,81 \mathrm{~g} / \mathrm{p} / \mathrm{s})$, untuk parameter KKK $(36,47 \%)$ yang dijumpai pada klon PB 340 tanpa paklobutrazol $\left(\mathrm{K}_{3} \mathrm{P}_{0}\right)$, fosfat anorganik $(4,92 \mathrm{mM})$ dan Thiol $(0,38 \mathrm{mM})$ tertinggi terdapat pada perlakuan $\mathrm{K}_{4} \mathrm{P}_{1}$ dan indeks penyumbatan terendah terdapat pada $\mathrm{K}_{3} \mathrm{P}_{2}$ $(18,71 \%)$. Hasil penelitian ini menjadi salah satu solusi untuk memperpendek tinggi tanaman belum menghasilkan (TBM), karena dapat menghambat pertambahan tinggi dan mempercepat pertambahan lilit batang tanaman.

Kata kunci: Anatomi; fisiologi lateks; klon; paklobutrazol; pertumbuhan tanaman

\section{PENDAHULUAN}

Kriteria matang sadap tanaman karet yang dianut hingga dewasa ini masih berdasarkan pada ketentuan yang sifatnya visual. Hamparan tanaman karet dinyatakan sudah memenuhi kriteria matang sadap apabila $60 \%$ dari populasi tegakan telah mencapai lilit batang $45 \mathrm{~cm}$. Kriteria seperti ini baru dapat dijumpai pada hamparan tanaman karet yang berumur 4,5 - 5 tahun (Anwar, 2006). Analisis ekonomi telah menunjukkan bahwa kerugian selama masa tanaman belum menghasilkan (TBM), termasuk di dalamnya ongkos dan waktu dapat ditutup lebih cepat dengan memperpendek masa non produktif (Anwar, 2006). Lateks mengandung partikel karet (isoprene) yang dihasilkan oleh tanaman karet dan merupakan produk sekunder yang tergolong sebagai terpen (politerpen), yang disintesis melalui lintasan asam mevalonat (MVA). Sebagai precursor dari isoprene adalah asetil $k o A$ atau asam asetat, tetapi dalam jaringan dipersiapkan berupa sukrosa yang mudah ditranslokasikan (Coucaud et al. 2009, Kekwick, 1989; West, 1990; Jacob et al., 1989).

Dari hasil penelitian Koryati (1998) diperoleh bahwa pada tanaman karet klon PB 260 (umur 2 tahun), aplikasi paklobrotazol baik melalui tanah maupun daun melambatkan pertambahan tinggi tanaman, sehingga dapat meningkatkan pertambahan lilit batang sekitar 50\% dibandingkan dengan kontrol. Selain itu hasil penelitian Koryati et al. (2015) juga menunjukkan bahwa beberapa klon karet yang diteliti pada umur 34 bulan di lapangan, aplikasi paklobutrazol melalui tanah lebih kuat menghambat tinggi tanaman, luas daun tetapi dapat meningkatkan diameter batang, tebal kulit dan jumlah cincin pembuluh lateks. Hal ini sangat penting pada tanaman karet semasa TBM karena lamanya umur non produktif ini sangat erat kaitannya dengan ukuran lilit batang dan tebal kulit.

Mekanisme kerja paklobutrazol bersifat menghambat biosintesis giberelin (ICI, 1986; Sponsel, 1987; Davis et al., 1988). Penghambatannya terjadi pada lintasan pembentukan kaurenoat, sehingga lintasan tersebut beralih peran untuk melaksanakan biosintesis asam absisat. Dampak dari proses tersebut ialah menghambat pertumbuhan vegetatif tanaman. Agar pemberiannya lebih efektif harus 
diperhatikan beberapa faktor, seperti iklim, stadia, fase pertumbuhan dan kondisi tanaman.

Penelitian paklobutrazol sudah diaplikasikan secara luas untuk memperpendek batang tanaman ornamental, sedangkan yang diaplikasi pada batang tanaman perkebunan masih terbatas. Wang et al. (1986) meneliti pengaruh paklobutrazol pada akumulasi karbohidrat pada kayu apel. Ternyata paklobutrazol yang diaplikasi melalui semprotan (daun) dan injeksi pada batang meningkatkan kadar karbohidrat berupa fruktosa, glukosa dan sukrosa pada jaringan kayu. Hasil penelitian ini sangat berguna pada tanaman karet, karena mendukung proses pembentukan lateks.

Lateks dihasilkan dari asimilat hasil fotosintesis dalam bentuk sukrosa, ditranslokasikan dari daun melalui pembuluh tapis ke dalam pembuluh lateks (Chaidamsari, 1987; Chantuma et al., 2006). Di dalam pembuluh lateks terdapat enzim seperti invertase yang akan mengatur proses perombakan sukrosa untuk pembentukan karet. Walaupun mekanisme kerja paklobutrazol menghambat GA-endogen melalui lintasan yang sama, hal ini tidak mempengaruhi produksi lateks yang dihasilkan dari tanaman yang diaplikasi paklobutrazol.

Dengan melihat lateks sebagai kumpulan sitoplasma dari sel-sel pembuluh lateks, maka analisisnya merupakan cerminan dari mekanisme metabolik yang berlangsung baik dalam pembentukannya, maupun mekanisme fisiologis tanaman secara keseluruhan. Secara fisiologis paklobutrazol meningkatkan kadar karbohidrat dalam jaringan kayu, partisi asimilat dari daun ke akar, meningkatkan respirasi akar, mengurangi kehilangan air akar (Wang et al., 1986). Selain itu paklobutrazol juga menekan pertumbuhan vegetatif, menghambat sel pada sub apical maristem dan mempertebal batang (Wattimena, 1988). Dengan berkurangnya pertumbuhan vegetatif maka pertumbuhan tanaman lebih kekar dan terbuka untuk mendapat penyinaran matahari optimum.
Pengaruh fisiologi ini sangat erat kaitannya dengan pertumbuhan tanaman karet belum menghasilkan. Untuk merangsang batang agar pertumbuhan meninggi tanaman dihambat untuk sementara oleh paklobutrazol, sehingga dampaknya ialah tanaman menjadi pendek dan pengaruhnya terjadi pada pembesaran lilit batang, sehingga masa non produktif dapat dipersingkat. Lilit batang dan tebal kulit juga mempunyai hubungan dengan produksi lateks (Sunariyo,1996; Novalina et al., 2008). Selain itu karakter fisiologi, anatomi kulit, pertumbuhan dan produksi karet merupakan parameter penting di dalam seleksi klon karet unggul (Woelan et al., 2013). Penggunaan klon karet unggul yang berproduksi tinggi merupakan syarat utama penentu keberhasilan agribisnis tanaman karet. Dengan demikian para pemulia tanaman karet terus berupaya untuk mendapatkan klon-klon unggul baru yang memiliki potensi hasil tinggi serta memiliki karakter agronomi yang diinginkan (Woelan et al., 2007).

Kajian bidang fisiologi dan biokimia lateks pada tanaman karet bermanfaat untuk menentukan karakteristik tanaman muda yang diduga memiliki produktivitas tinggi (Jacob et al., 1989). Apabila parameter fisiologi dan biokimia itu dirumuskan secara tepat dan dilaksanakan dengan akurat, maka profil dari suatu klon dapat digambarkan potensi produksinya sehingga dapat diketahui secara dini (Bricard \& Nicolas, 1989). Adanya perbedaan karakteristik fisiologi lateks dan anatomi dari jenis klon yang berbeda akan mempermudah seleksi terhadap karakter klon yang diinginkan (Jacob et al., 1989).

Tujuan utama penelitian ini adalah untuk mengetahui bagaimana penggunaan paklobutrazol dapat memperpendek masa TBM, dan untuk mempelajari produksi lateks serta karakter fisiologi lateks beberapa klon karet pada penyadapan awal.

\section{BAHAN DAN METODE}

Penelitian ini dilaksanakan di KSO Kebun Karang Inong PT Perkebunan Nusantara I di Kabupaten Aceh Timur dan 
PT Perkebunan Nusantara III. Kebun Karang Inong berada pada ketinggian $51 \mathrm{~m}$ dari permukaan laut, dengan topografi datar sampai bergelombang. Penelitian ini dilaksanakan mulai bulan Maret 2013 sampai dengan Oktober 2014 dan analisis lateks pada bulan Juli 2015. Klon yang digunakan dalam penelitian ini ada lima klon karet yaitu PB 260, PB 340, PB 330, IRR 5, dan IRR 107. Umur tanaman karet yang digunakan adalah tanaman berumur 28 bulan (tahun tanam Desember 2010).

Penelitian ini disusun berdasarkan Rancangan Tersarang (Nested Design) dua faktor yaitu faktor klon dan faktor paklobutrazol. Faktor klon $(\mathrm{K})$ terdiri dari 5 jenis klon yaitu $\mathrm{K}_{1}=$ Klon $\mathrm{PB} 260, \mathrm{~K}_{2}=$ Klon $\mathrm{PB}$ 330, $\mathrm{K}_{3}=\mathrm{PB} 340, \mathrm{~K}_{4}=$ IRR 107, dan $\mathrm{K}_{5}=$ IRR 5. Sedangkan faktor Paklobutrazol $(\mathrm{P})$ terdiri dari 3 taraf yaitu $\mathrm{P}_{0}=0$ (Kontrol tanpa paklobutrazol), $\mathrm{P}_{1}=$ paklobutrazol $500 \mathrm{ppm}$ (di aplikasikan melalui tanah) dan $\mathrm{P}_{2}=$ paklobutrazol 500 ppm (di aplikasikan melalui daun). Perlakuan diulang dua kali, namun tersarang dalam faktor perlakuan jenis klon, sehingga jumlah satuan percobaan adalah $5 \times 3 \times 2=30$ satuan percobaan. Setiap satuan percobaan terdiri dari 4 tanaman, maka jumlah tanaman yang digunakan adalah 120 tanaman.

Masing-masing klon dipilih 24 tanaman yang memiliki homogenitas relatif tinggi. Kriteria pemilihan tanaman meliputi tinggi tanaman, ukuran lilit batang, kondisi tajuk dan bebas dari penyakit akar dan daun. Jumlah tanaman tersebut dibagi dua kelompok sebagai ulangan dan masingmasing (12 pohon). Untuk menguji masingmasing perlakuan yang dicobakan dilakukan Analisis Ragam. Apabila hasil analisis menunjukkan beda nyata, dilanjutkan dengan uji Duncan Multiple Range Test (DMRT), sedangkan untuk melihat hubungan antar sifat yang diamati maka dilakukan analisis korelasi dengan menggunakan software SPSS ver.18.

Aplikasi paklobutrazol melalui tanah diberikan hanya dua kali yaitu pada saat pelaksanaan penelitian dan 6 Bulan Setelah Perlakuan (BSP), sedangkan aplikasi paklobutrazol melalui penyemprotan permukaan daun diberikan sebanyak 10 kali mulai dari pelaksanaan penelitian dengan interval 1 bulan sekali.

Pengamatan parameter dilakukan pada umur 46 bulan di lapangan yaitu pengamatan pertambahan tanaman meliputi :

1. Sifat pertumbuhan meliputi lilit batang (cm) yang diukur pada ketinggian $100 \mathrm{~cm}$ di atas permukaan tanah, dan tebal kulit $(\mathrm{mm})$ diukur dengan menggunakan alat ukur ketebalan kulit.

2. Sifat pertumbuhan tinggi tanaman yang diukur dengan menggunakan bambu atau kayu yang telah diberi ukuran/meteran. Diukur di atas kaki gajah sampai pucuk tanaman yang tertinggi pada tanaman yang lurus.

3. Anatomi kulit meliputi jumlah pembuluh lateks dan diameter pembuluh lateks yang diamati dengan menggunakan metode Gomez et al. (1982), dengan cara mengambil contoh kulit berdiameter 1 $\mathrm{cm}$ pada ketinggian $100 \mathrm{~cm}$ di atas permukaan tanah.

4. Produksi karet $(\mathrm{g} / \mathrm{p} / \mathrm{s})$ diamati pada umur tanaman 54 bulan di lapangan dengan penyadapan awal pada penyadapan pisau ke empat. Produksi per tanaman diamati dengan mengukur volume lateks yang dihasilkan dari tiap tanaman, yang kemudian dikonversi menjadi g/p/s. Kadar karet kering (KKK) diukur dengan cara meneteskan lateks segar 2 g pada plat kaca, diratakan dan ditimbang bobot basahnya $\left(\mathrm{B}_{\text {basah }}\right)$, kemudian dikeringkan menggunakan oven dengan suhu sekitar $100^{\circ} \mathrm{C}$ selama $2 \times 24$ jam sehingga menjadi tetap bobotnya $\left(\mathrm{B}_{\text {kering }}\right)$. Perhitungan kadar karet kering dengan menggunakan persamaan berikut:

Kadar Karet Kering KKK $=\frac{\text { Bobot Kering }}{\text { Bobot Basah }} \times 100 \% . .(1)$

5. Sifat fisiologi lateks meliputi kadar sukrosa dan fosfat anorganik diukur dengan menggunakan 1 contoh berupa 
serum lateks/TCA (Trichloroacetic acid). Serum lateks dibuat dengan cara mencampur $1 \mathrm{~mL}$ lateks dengan $9 \mathrm{~mL}$ TCA. Kadar sukrosa diukur berdasarkan metode Dische (1962), yaitu berdasarkan reaksinya dengan anthrone menghasilkan turunan furfural yang berwarna hijau biru yang terabsorbsi pada panjang gelombang $627 \mathrm{~nm}$. Pengukuran fospat anorganik dilakukan dengan metode Taussky dan Shorr (1953), yaitu berdasarkan prinsip reaksi dengan molibdat menghasilkan kompleks Pimolibdat berwarna biru yang terabsorsi pada panjang gelombang 750 $\mathrm{nm}$. Nilai absorban diukur dengan spektrofotometer Beckham DU 650. Indeks penyumbatan diamati dengan membandingkan volume lateks yang mengalir pada 5 menit pertama dengan total volume lateks yang dihasilkan dalam satu kali sadap dikali $100 \%$, sedangkan penyumbatan ditentukan berdasarkan Milford et al (1969). Indeks Penyumbatan (IP) ditentukan dengan cara berikut volume lateks 5 menit pertama total volume lateks $\mathrm{x} 100$. Sedangkan pH diamati dengan menggunakan $\mathrm{pH}$ meter, yang dilakukan segera saat lateks menetes setelah disadap. Pembacaan pH pada 2-5 menit pertama (Do et al., 1996)

Pada penelitian ini data yang diolah adalah data pertambahan pada pengamatan 18 BSP atau tanaman berumur 46 bulan di lapangan. Data diperoleh dari pengurangan umur tanaman 46 bulan dikurangi pada pengamatan awal (28 bulan). Untuk data hasil yaitu produksi dan karakter fisiologi lateks diamati pada tanaman 54 bulan di lapangan yaitu data diperoleh pada penyadapan awal pada penyadapan pisau ke empat tanpa menggunakan stimulan. Penyadapan dilakukan pada bulan Juli 2015 umur tanaman 54 bulan, karena pada bulan Oktober 2014 (umur tanaman 46 bulan) di lapangan masih banyak tanaman yang belum sesuai dengan kriteria matang sadap, (walaupun dari tanaman sampel yang di teliti sudah mencapai kriteria matang sadap dengan lilit batang sudah $\pm 45 \mathrm{~cm}$ ), hal ini terjadi karena penulis melakukan penelitian di kebun KSO PT Perkebunan Nusantara I dan PT Perkebuan Nusantara III dan penyadapan baru bisa dilakukan setelah mendapat persetujuan dari perusahaan.

\section{HASIL DAN PEMBAHASAN}

\section{Pertumbuhan dan Anatomi Tanaman}

Hasil analisis statistik menunjukkan bahwa setiap perlakuan paklobutrazol dan klon yang diuji memberikan pengaruh nyata yang disajikan pada Tabel 1 . Terlihat bahwa masing-masing klon yang diuji menunjukkan perbedaan terhadap parameter yang diamati. Pertambahan tinggi tanaman dan lilit batang terbesar terdapat pada klon PB 330, pertambahan tebal kulit dan diameter pembuluh lateks terbesar terdapat pada klon PB 260, sedangkan pertambahan jumlah pembuluh lateks terbesar terdapat pada klon IRR 107. Sedangkan perlakuan paklobutrazol nyata menekan pertambahan tinggi tanaman, tetapi aplikasi paklobutrazol melalui tanah dapat meningkatkan pertambahan lilit batang, tebal kulit dan diameter pembuluh lateks.

Hasil observasi juga menunjukkan bahwa terdapat korelasi antara tinggi tanaman dengan lilit batang dan tebal kulit. Seperti telah diketahui bahwa salah satu efek yang paling nyata dari paklobutrazol adalah memodifikasi pertumbuhan. Perubahan dalam perkembangan ini memanifestasikan fenomena melalui penghambatan biosintesis giberelin. Penghambatannya terjadi pada lintasan pembentukan kaurenoat dari oksidasi kaurena, sehingga lintasan ini berubah peran untuk melaksanakan biosintesis asam absisat (ICI, 1986; Sponsel, 1987; Davis et al., 1988). Dampak dari proses tersebut ialah menekan pertumbuhan pemanjangan sel vegetatif sehingga pertumbuhan tinggi tanaman klon karet semasa TBM dihambat dan efeknya ialah terhadap pembesaran batang dan ketebalan kulit karena beralihnya penggunaan fotosintat.

Hasil penelitian pada lima klon yang diuji selama 18 bulan (dari umur 28 bulan sampai dengan 46 bulan di lapangan), bahwa klon yang lebih cepat pertumbuhan 
Tabel 1. Rataan pertambahan tinggi tanaman, lilit batang, tebal kulit, jumlah pembuluh lateks (JPL) dan diameter pembuluh lateks (DPL) umur 46 bulan pada perlakuan klon dan paklobutrazol

Table 1. Avarage increasing of plant height, girth, bark thickness, number of latex vessel (JPL) and diameter of latex vessel (DPL) at the age of 46 months by clones and paclobutrazol treatment

\begin{tabular}{|c|c|c|c|c|c|}
\hline \multirow[b]{2}{*}{$\begin{array}{l}\text { Perlakuan } \\
\text { Treatment }\end{array}$} & \multicolumn{5}{|c|}{$\begin{array}{l}\text { Data pertambahan dari umur } 28 \text { ke } 46 \text { bulan } \\
\text { Increasing data at the age of } 28 \text { to } 46 \text { months }\end{array}$} \\
\hline & $\begin{array}{l}\text { Tinggi } \\
\text { tanaman } \\
\text { Plant } \\
\text { height } \\
\text { (m) }\end{array}$ & $\begin{array}{l}\text { Lilit batang } \\
\text { Girth } \\
\text { (cm) }\end{array}$ & $\begin{array}{c}\text { Tebal kulit } \\
\text { Bark } \\
\text { thickness } \\
\text { (mm) }\end{array}$ & $\begin{array}{c}\text { Jumlah } \\
\text { pembuluh } \\
\text { lateks } \\
\text { Number of } \\
\text { latex vessels }\end{array}$ & $\begin{array}{c}\text { Diameter } \\
\text { pembuluh } \\
\text { lateks } \\
\text { Diameter of } \\
\text { latex vessel } \\
(\mathrm{m} \mu)\end{array}$ \\
\hline \multicolumn{6}{|c|}{ Klon $(\mathrm{K})$} \\
\hline $\mathrm{K}_{1}=\mathrm{PB} 260$ & $3,00 \mathrm{~b}$ & $21,58 \mathrm{c}$ & $3,17 \mathrm{a}$ & $2,69 \mathrm{c}$ & $14,01 \mathrm{a}$ \\
\hline $\mathrm{K}_{2}=\mathrm{PB} 330$ & $3,45 \mathrm{a}$ & $22,74 \mathrm{a}$ & $2,99 \mathrm{a}$ & $3,00 \mathrm{~b}$ & $13,52 \mathrm{ab}$ \\
\hline $\mathrm{K}_{3}=\mathrm{PB} 340$ & $3,26 \mathrm{a}$ & $21,73 \mathrm{bc}$ & $3,13 \mathrm{a}$ & $2,93 \mathrm{bc}$ & $13,24 \mathrm{~b}$ \\
\hline $\mathrm{K}_{4}=\mathrm{IRR} 107$ & 3,39 a & $21,39 \mathrm{c}$ & $2,75 \mathrm{~b}$ & $3,60 \mathrm{a}$ & 13,96 a \\
\hline $\mathrm{K}_{5}=\mathrm{IRR} 5$ & $3,28 \mathrm{a}$ & $22,44 \mathrm{ab}$ & $2,79 \mathrm{~b}$ & $2,86 \mathrm{bc}$ & $13,43 \mathrm{ab}$ \\
\hline \multicolumn{6}{|c|}{ Paklobutrazol (P) } \\
\hline $\mathrm{P}_{0}=0$ (kontrol) & 3,85 a & $21,30 \mathrm{~b}$ & $2,67 \mathrm{c}$ & $2,90 \mathrm{a}$ & $13,41 \mathrm{~b}$ \\
\hline $\mathrm{P}_{1}=500 \mathrm{ppm}$ (tanah) & $2,76 \mathrm{c}$ & $22,50 \mathrm{a}$ & $3,26 \mathrm{a}$ & 3,06 a & 13,92 a \\
\hline $\mathrm{P}_{2}=500 \mathrm{ppm}$ (daun) & $3,22 \mathrm{~b}$ & $22,13 \mathrm{a}$ & $2,96 \mathrm{~b}$ & $3,09 \mathrm{a}$ & $13,56 \mathrm{ab}$ \\
\hline
\end{tabular}

Keterangan: Angka yang diikuti huruf yang sama pada kolom yang sama, menunjukkan berbeda tidak nyata pada taraf $5 \%$ berdasarkan Uji DMRT

Remaks: Figures followed by the same letter in the same column were not significantly different at $5 \%$ level according to Duncan Multiple Range Test

lilit batangnya adalah klon PB $330\left(\mathrm{~K}_{2}=\right.$ $46,28 \mathrm{~cm})$, diikuti IRR $5\left(\mathrm{~K}_{5}=46,15 \mathrm{~cm}\right), \mathrm{PB}$ $340\left(\mathrm{~K}_{3}=45,48 \mathrm{~cm}\right)$, IRR $107\left(\mathrm{~K}_{4}=45,21 \mathrm{~cm}\right)$ dan PB $260\left(\mathrm{~K}_{1}=45,20 \mathrm{~cm}\right)$ pada umur 46 bulan di lapangan (Lampiran 2). Jadi lilit batang untuk klon yang diuji sudah memenuhi kriteria matang sadap. Hal ini diduga bahwa klon-klon yang diuji merupakan klon anjuran komersial yang dikelompokkan menjadi dua kelompok yaitu klon PB 330, PB 260 dan PB 340 termasuk kedalam klon penghasil lateks, sedangkan klon IRR 5 dan IRR 107 adalah klon penghasil lateks dan kayu (Daslin, 2014; Daslin et al., 2009; Anwar, 2006).

Dari hasil analisis sidik ragam terlihat bahwa interaksi perlakuan klon dan paklobutrazol ( $\left.\begin{array}{llll}K & \mathrm{x} & \mathrm{P}\end{array}\right)$ hanya nyata pengaruhnya terhadap pertambahan tinggi tanaman dan jumlah pembuluh lateks, sedangkan pada parameter yang lain tidak menunjukkan pengaruh nyata. Walaupun pertambahan lilit batang pengaruhnya tidak nyata, tapi perlakuan aplikasi paklobutrazol cenderung meningkatkan pertambahan lilit batang. Uji beda rataan pertambahan tinggi tanaman, jumlah pembuluh lateks, dan lilit batang disajikan pada Tabel 2 .

Pada Tabel 2 terlihat bahwa bahwa klon tanpa paklobutrazol menyebabkan pertambahan tinggi tanaman meningkat nyata dan terbesar pada klon PB 330 tanpa paklobutrazol $\left(\mathrm{K}_{2} \mathrm{P}_{0}\right)$, tetapi bila klon diaplikasi paklobutrazol melalui daun $\left(\mathrm{P}_{2}\right)$ maka pertambahan tinggi tanaman tertekan, sedangkan bila paklobutrazol diberikan melalui tanah $\left(\mathrm{P}_{1}\right)$ maka pertambahan tinggi klon semakin tertekan secara nyata. Untuk parameter pertambahan lilit batang terlihat bahwa aplikasi paklobutrazol cenderung meningkatkan pertambahan lilit batang secara tidak nyata. 
Tabel 2. Rataan pertambahan tinggi tanaman dan jumlah pembuluh lateks umur 46 bulan pada interaksi perlakuan klon dan paklobutrazol

Table 2. Average increasing of plant height and number of latex vessels at the age of 46 months by clones and paclobutrazol treatment interaction

\begin{tabular}{|c|c|c|c|c|}
\hline \multirow[b]{2}{*}{$\begin{array}{l}\text { Klon } \\
\text { Clone } \\
\text { (K) }\end{array}$} & \multirow[b]{2}{*}{$\begin{array}{l}\text { Paklobutrazol } \\
\text { Paclobutrazol } \\
\text { (P) }\end{array}$} & \multicolumn{3}{|c|}{$\begin{array}{l}\text { Data pertambahan dari umur } 28 \text { ke } 46 \text { bulan } \\
\text { Increasing data at the age of } 28 \text { to } 46 \text { months }\end{array}$} \\
\hline & & $\begin{array}{l}\text { Tinggi tanaman } \\
\text { Plant height } \\
\text { (m) }\end{array}$ & $\begin{array}{c}\text { Jumlah } \\
\text { pembuluh } \\
\text { lateks } \\
\text { Number of latex } \\
\text { vessels }\end{array}$ & $\begin{array}{l}\text { Lilit batang } \\
\text { Girth } \\
\text { (cm) }\end{array}$ \\
\hline $\mathrm{K}_{1}=\mathrm{PB} 260$ & $\begin{array}{l}\mathrm{P}_{0}=0 \text { (kontrol) } \\
\mathrm{P}_{1}=500 \mathrm{ppm} \text { (tanah) } \\
\mathrm{P}_{2}=500 \mathrm{ppm} \text { (daun) }\end{array}$ & $\begin{array}{l}3,26 \mathrm{~b} \\
2,62 \mathrm{~d} \\
3,12 \mathrm{bc} \\
\end{array}$ & $\begin{array}{c}2,64 \mathrm{efg} \\
2,57 \mathrm{fg} \\
2,86 \mathrm{def} \\
\end{array}$ & $\begin{array}{l}20,78 \mathrm{a} \\
21,94 \mathrm{a} \\
22,03 \mathrm{a} \\
\end{array}$ \\
\hline $\mathrm{K}_{2}=\mathrm{PB} 330$ & $\begin{array}{l}\mathrm{P}_{0}=0 \text { (kontrol) } \\
\mathrm{P}_{1}=500 \mathrm{ppm} \text { (tanah) } \\
\mathrm{P}_{2}=500 \mathrm{ppm} \text { (daun) }\end{array}$ & $\begin{array}{c}4,02 \mathrm{a} \\
3,04 \mathrm{bc} \\
3,28 \mathrm{~b} \\
\end{array}$ & $\begin{array}{l}2,79 \mathrm{~d}-\mathrm{g} \\
3,21 \mathrm{bcd} \\
3,00 \mathrm{c}-\mathrm{f} \\
\end{array}$ & $\begin{array}{l}22,29 \mathrm{a} \\
23,23 \mathrm{a} \\
22,70 \mathrm{a} \\
\end{array}$ \\
\hline $\mathrm{K}_{3}=\mathrm{PB} 340$ & $\begin{array}{l}\mathrm{P}_{0}=0 \text { (kontrol) } \\
\mathrm{P}_{1}=500 \mathrm{ppm} \text { (tanah) } \\
\mathrm{P}_{2}=500 \mathrm{ppm} \text { (daun) }\end{array}$ & $\begin{array}{l}3,98 \mathrm{a} \\
2,63 \mathrm{~d} \\
3,17 \mathrm{~b}\end{array}$ & $\begin{array}{l}3,14 \mathrm{bcd} \\
3,00 \mathrm{c}-\mathrm{f} \\
2,64 \mathrm{efg}\end{array}$ & $\begin{array}{l}20,84 \mathrm{a} \\
22,17 \mathrm{a} \\
22,19 \mathrm{a}\end{array}$ \\
\hline $\mathrm{K}_{4}=\operatorname{IRR} 107$ & $\begin{array}{l}\mathrm{P}_{0}=0 \text { (kontrol) } \\
\mathrm{P}_{1}=500 \mathrm{ppm} \text { (tanah) } \\
\mathrm{P}_{2}=500 \mathrm{ppm} \text { (daun) }\end{array}$ & $\begin{array}{c}4,02 \mathrm{a} \\
2,86 \mathrm{~cd} \\
3,31 \mathrm{~b} \\
\end{array}$ & $\begin{array}{r}2,36 \mathrm{~g} \\
3,07 \mathrm{cde} \\
3,14 \mathrm{bcd} \\
\end{array}$ & $\begin{array}{l}20,85 \mathrm{a} \\
21,75 \mathrm{a} \\
21,58 \mathrm{a}\end{array}$ \\
\hline$\overline{\mathrm{K}_{5}}=\mathrm{IRR} 5$ & $\begin{array}{l}\mathrm{P}_{0}=0 \text { (kontrol) } \\
\mathrm{P}_{1}=500 \mathrm{ppm} \text { (tanah) } \\
\mathrm{P}_{2}=500 \mathrm{ppm} \text { (daun) }\end{array}$ & $\begin{array}{l}, 99 \mathrm{a} \\
2,63 \mathrm{~d} \\
3,23 \mathrm{~b}\end{array}$ & $\begin{array}{c}3,57 \mathrm{ab} \\
3,43 \mathrm{abc} \\
3,79 \mathrm{a} \\
\end{array}$ & $\begin{array}{l}21,75 \mathrm{a} \\
23,42 \mathrm{a} \\
22,16 \mathrm{a} \\
\end{array}$ \\
\hline
\end{tabular}

Keterangan: Angka yang diikuti huruf yang sama, menunjukkan berbeda tidak nyata pada taraf $5 \%$ berdasarkan Uji DMRT.

Remaks: Figures followed by the same letter were not significantly different at 5\% level according to Duncan Multiple Range Test

Hal ini sesuai dengan hasil penelitian Koryati et al. (2015) diperoleh bahwa pada beberapa klon karet yang diteliti pada umur 34 bulan di lapangan menunjukkan bahwa aplikasi paklobutrazol melalui tanah (P1) dibanding melalui daun (P2) lebih kuat menghambat pertambahan tinggi tanaman, luas daun dan meningkatkan pertambahan lilit batang, tebal kulit dan jumlah cincin pembuluh lateks. Hasil penelitian ini sangat penting untuk tanaman karet semasa Tanaman Belum Menghasilkan (TBM) karena dapat mempercepat matang sadap, selain itu perlu dipelajari bagaimana produksi lateks serta karakter fisiologi lateks pada penyadapan awal.

Dari hasil penelitian terlihat juga bahwa aplikasi paklobutrazol melalui tanah pada klon IRR $5 \quad\left(\mathrm{~K}_{5} \mathrm{P}_{1}\right)$ cenderung dapat meningkatkan pertambahan lilit batang sebesar 23,42 cm $(46,50 \mathrm{~cm})$, dan aplikasi paklobutrazol baik melalui tanah maupun daun pada klon PB $330\left(\mathrm{~K}_{2} \mathrm{P}_{1}\right)$ juga cenderung meningkatkan pertambahan lilit batang sebesar 23,23 cm $(46,50 \mathrm{~cm})$ dan pada perlakuan $\mathrm{K}_{2} \mathrm{P}_{2}$ sebesar $22,70 \mathrm{~cm}(47,60 \mathrm{~cm})$. Sedangkan pertambahan lilit batang terendah terdapat pada klon PB 340 tanpa paklobutrazol $\left(\mathrm{K}_{3} \mathrm{P}_{0}\right)$ pertambahan hanya 20,84 cm (40,15 cm) (Tabel 2 dan Lampiran 2).

Jadi kombinasi perlakuan klon dengan aplikasi paklobutrazol baik melalui tanah maupun daun dapat mempercepat matang sadap, karena pada umur tanaman 46 bulan di lapangan tanaman sudah memenuhi kriteria matang sadap dengan ukuran lilit batang $(>45 \mathrm{~cm})$. Sementara tanaman di 
lokasi penelitian kebun Karang Inong KSO PTPN I baru bisa dilakukan penyadapan pada umur 54 bulan (4.5 tahun) dengan ketentuan kriteria matang sadap (60\% dari areal tanaman tegakan dengan lilit batang $45 \mathrm{~cm}$ ). Aplikasi paklobutrazol $500 \mathrm{ppm}$ baik melalui tanah maupun daun dapat mempercepat matang sadap sekitar 8 bulan (54 bulan - 46 bulan) di lokasi penelitian kebun Karang Inong KSO PTPN-I. Hasil penelitian Koryati (1998, 2015) di dukung penelitian Sarkar et al. (2015) pada pembibitan karet klon RRII 429 di polybag, bahwa aplikasi paklobutrazol dengan konsentrasi $50 \mathrm{mg}$ dapat memodifikasi morfologi tanaman, di mana tanaman semakin pendek dan seragam, namun dapat meningkatkan diameter batang dan meningkatkan perkembangan akar.

Aplikasi paklobutrazol melalui tanah $\left(\mathrm{P}_{1}\right)$ lebih kuat menghambat pertambahan tinggi tanaman klon karet dibanding melalui daun $\left(\mathrm{P}_{2}\right)$. Hal ini sesuai dengan hasil penelitian Davis et al. (1988) pada tanaman apel, menunjukkan bahwa paklobutrazol umumnya lebih efektif menghambat pertumbuhan ketika diaplikasi melalui tanah atau langsung ke batang dibandingkan aplikasi melalui daun. Studi laboratorium memperlihatkan bahwa kandungan paklobutrazol pada tanah juga berhubungan dengan kandungan bahan organik tanah, kandungan tanah liat (lempung) dan Kapasitas Tukar Kation. Pengangkutan melalui akar akan bergantung pada relatif dekatnya bahan kimia paklobutrazol ke akar (Davis et al., 1988). Sedangkan pada interaksi perlakuan klon dan paklobutrazol pada pertambahan jumlah pembuluh lateks (Tabel 2), terlihat bahwa pertambahan jumlah pembuluh lateks terbesar diperoleh pada klon IRR 5 dengan aplikasi paklobutrazol melalui daun $\left(\mathrm{K}_{5} \mathrm{P}_{2}\right)$, yang berbeda tidak nyata dengan kombinasi perlakuan $\mathrm{K}_{5} \mathrm{P}_{1}$ dan $\mathrm{K}_{5} \mathrm{P}_{\mathrm{o}}$. Pertambahan jumlah pembuluh lateks terkecil terdapat pada klon IRR 107 tanpa aplikasi paklobutrazol $\left(\mathrm{K}_{4} \mathrm{P}_{0}\right)$.

Sebagaimana dinyatakan sebelumnya, penekanan pertumbuhan vegetatif atau penekanan tinggi tanaman klon karet ini terjadi karena mekanisme kerja paklobutrazol yang menghalangi produksi giberelin endogen, sehingga konsentrasi GA rendah. Namun lebih rendahnya konsentrasi tidak sampai menghalangi pembentukan sel-sel baru tetapi hanya menghambat perpanjangan sel (ICI, 1986; Sponsel, 1987; Davis et al., 1988).

\section{Produksi Lateks per Tanaman dan Karakter Fisiologi Lateks}

Respon terpenting setiap klon tanaman karet terhadap perlakuan tercermin dari produksi, walaupun sebenarnya dari penelitian yang dilakukan produksi belum menjadi patokan. Pada penelitian ini belum dilakukan penyadapan secara rutin, meskipun data tetap diambil dari penyadapan awal pada penyadapan pisau ke empat yaitu untuk mempelajari bagaimana produksi dan karakter fisiologi lateks tersebut. Data rataan produksi lateks per tanaman dan parameter fisiologi lateks sukrosa, fosfat anorganik (FA), tiol, kadar karet kering (KKK), $\mathrm{pH}$ lateks dan indeks penyumbatan (IP) dapat dilihat pada Tabel 3.

Pada Tabel 3 terlihat bahwa masingmasing klon nyata mempengaruhi produksi lateks per tanaman. Klon PB $340 \quad\left(\mathrm{~K}_{3}\right)$ menghasilkan produksi lateks per tanaman lebih tinggi $(20,63 \mathrm{~g} / \mathrm{p} / \mathrm{s})$ dan berbeda nyata dengan klon IRR $107\left(\mathrm{~K}_{4}\right)$, PB $260\left(\mathrm{~K}_{1}\right), \mathrm{PB}$ $330\left(\mathrm{~K}_{2}\right)$ dan IRR $5\left(\mathrm{~K}_{5}\right)$, tapi diantara klon IRR 105 dan klon PB 330 saling berbeda tidak nyata terhadap produksi lateks per tanaman. Untuk parameter KKK, sukrosa, FA dan tiol tertinggi terdapat pada klon IRR 107, sedangkan $\mathrm{pH}$ tertinggi terdapat pada klon PB 340 dan Indeks penyumbatang terdapat pada klon PB 330.

Pemberian paklobutrazol juga meningkatkan produksi lateks per tanaman, aplikasi melalui tanah $\left(\mathrm{P}_{1}\right)$ lebih tinggi dibandingkan dengan aplikasi melalui daun $\left(\mathrm{P}_{2}\right)$ secara tidak nyata. Pemberian paklobutrazol juga nyata meningkatkan KKK dan kadar FA, dimana aplikasi melalui tanah $\left(\mathrm{P}_{1}\right)$ memberikan KKK lebih tinggi, sedangkan kadar FA diperoleh dari aplikasi melalui daun $\left(\mathrm{P}_{2}\right)$. Untuk kadar tiol, $\mathrm{pH}$ dan IP tanpa paklobutrazol $\left(\mathrm{P}_{0}\right)$ lebih tinggi dibandingkan dengan aplikasi paklobutrazol 
Tabel 3. Uji beda rataan produksi lateks per tanaman dan parameter fisiologi lateks pada perlakuan klon dan paklobutrazol pada umur 54 bulan

Table 3. Mean different test of latex yield per tree and physiological character of latex by clones and paclobutrazol treatment at age of 54 months

\begin{tabular}{|c|c|c|c|c|c|c|c|}
\hline \multirow[b]{2}{*}{$\begin{array}{l}\text { Perlakuan } \\
\text { Treatment }\end{array}$} & \multicolumn{7}{|c|}{$\begin{array}{l}\text { Produksi lateks dan parameter fisiologi lateks } \\
\text { Latex yield and latex physiological parameters }\end{array}$} \\
\hline & $\begin{array}{l}\text { Produksi } \\
\text { lateks } \\
\text { (g/p/s) } \\
\text { Latex } \\
\text { Yield } \\
(\mathrm{g} / \mathrm{t} / \mathrm{t})\end{array}$ & $\begin{array}{l}\text { KKK } \\
D R C \\
(\%)\end{array}$ & $\begin{array}{l}\text { Sukrosa } \\
\text { Sucrose } \\
(\mathrm{mM})\end{array}$ & $\begin{array}{c}\mathrm{FA} \\
P i \\
(\mathrm{mM})\end{array}$ & $\begin{array}{l}\text { Tiol } \\
\text { Thiol } \\
(m M)\end{array}$ & $\begin{array}{l}\mathrm{pH} \\
\mathrm{pH}\end{array}$ & $\begin{array}{l}\text { IP } \\
P I \\
(\%)\end{array}$ \\
\hline \multicolumn{8}{|c|}{ Klon $(\mathrm{K})$} \\
\hline $\mathrm{K}_{1}=\mathrm{PB} 260$ & $15,51 \mathrm{c}$ & $34,60 \mathrm{c}$ & $3,75 \mathrm{~d}$ & $3,62 \mathrm{c}$ & $0,32 \mathrm{~b}$ & $6,80 \mathrm{c}$ & $22,00 \mathrm{~d}$ \\
\hline $\mathrm{K}_{2}=\mathrm{PB} 330$ & $12,87 \mathrm{~d}$ & $34,23 \mathrm{c}$ & $3,96 \mathrm{c}$ & $3,29 \mathrm{~d}$ & $0,31 \mathrm{~cd}$ & $6,79 c$ & $31,31 \mathrm{a}$ \\
\hline $\mathrm{K}_{3}=\mathrm{PB} 340$ & $20,63 \mathrm{a}$ & $33,49 d$ & $5,45 \mathrm{~b}$ & $4,47 \mathrm{~b}$ & $0,30 \mathrm{~d}$ & $7,02 \mathrm{a}$ & $19,35 \mathrm{e}$ \\
\hline $\mathrm{K}_{4}=\operatorname{IRR} 107$ & $18,76 \mathrm{~b}$ & $36,25 \mathrm{a}$ & $6,92 \mathrm{a}$ & $4,80 \mathrm{a}$ & $0,37 \mathrm{a}$ & $6,93 \mathrm{~b}$ & $25,28 \mathrm{c}$ \\
\hline $\mathrm{K}_{5}=\mathrm{IRR} 5$ & $12,51 \mathrm{~d}$ & $35,18 \mathrm{~b}$ & $3,63 d$ & $3,26 \mathrm{~d}$ & $0,31 \mathrm{c}$ & $6,82 \mathrm{c}$ & $30,23 \mathrm{~b}$ \\
\hline \multicolumn{8}{|c|}{ Paklobutrazol (P) } \\
\hline $\mathrm{P}_{0}=0$ (kontrol) & $15,47 \mathrm{~b}$ & $34,06 \mathrm{~b}$ & $4,82 \mathrm{a}$ & $3,82 \mathrm{~b}$ & $0,33 \mathrm{a}$ & $6,90 \mathrm{a}$ & $26,88 \mathrm{a}$ \\
\hline $\mathrm{P}_{1}=500 \mathrm{ppm}(\tan a \mathrm{~h})$ & $16,54 \mathrm{a}$ & $35,13 \mathrm{a}$ & $4,65 \mathrm{a}$ & $3,85 \mathrm{~b}$ & $0,32 \mathrm{~b}$ & $6,88 \mathrm{a}$ & $24,93 \mathrm{~b}$ \\
\hline $\mathrm{P}_{2}=500 \mathrm{ppm}$ (daun) & $16,15 \mathrm{a}$ & $35,06 \mathrm{a}$ & $4,75 \mathrm{a}$ & $4,00 \mathrm{a}$ & $0,32 \mathrm{~b}$ & $6,83 \mathrm{~b}$ & $25,09 \mathrm{~b}$ \\
\hline
\end{tabular}

Keterangan: Angka yang diikuti huruf kecil yang sama pada kolom yang sama, menunjukkan berbeda tidak nyata pada taraf $5 \%$ berdasarkan Uji DMRT.

Remaks: Figures followed by the same letter in the same column were not significantly different at 5\% level according to Duncan Multiple Range Test

baik melalui tanah maupun daun, sedangkan kadar sukrosa pemberian paklobutrazol berbeda tidak nyata.

Dari hasil analisis sidik ragam bahwa interaksi faktor klon dan paklobutrazol nyata pengaruhnya terhadap produksi lateks per tanaman dan karakter fisiologi lateks. Uji beda rataan produksi lateks per tanaman pada interaksi klon dan paklobutrazol disajikan pada Tabel 4. Dari Tabel 4 dapat dilihat bahwa, interaksi perlakuan klon dan paklobutrazol terhadap produksi lateks per tanaman, menunjukkan bahwa pada perlakuan $\mathrm{K}_{3} \mathrm{P}_{0}$ merupakan perlakuan yang menghasilkan produksi per tanaman tertinggi $( \pm 22,81 \mathrm{~g} / \mathrm{p} / \mathrm{s})$, sedangkan produksi per tanaman terendah diperoleh pada perlakuan $\mathrm{K}_{5} \mathrm{H}_{1} \quad( \pm 12,20$ $\mathrm{g} / \mathrm{p} / \mathrm{s})$.

Hal ini diduga bahwa klon PB 340 merupakan klon penghasil lateks, yang memiliki ciri produksi awal tinggi, produksi lanjutan meningkat, pertumbuhan lilit batang agak lambat. Sementara klon IRR
107 merupakan klon penghasil lateks-kayu, yang memiliki ciri produksi awal rendahsedang, produksi lanjutan meningkat (Aidi Daslin et al., 2009). Selain itu analisis fisiologi tanaman diduga juga merupakan cara yang berguna untuk menentukan kondisi tanaman, seperti kesehatan, potensi produksi maupun waktu buka sadap.

Interaksi klon dan paklobutrazol terhadap KKK, kadar sukrosa, FA dan tiol menunjukkan bahwa KKK, FA dan tiol tertinggi diperoleh pada perlakuan $\mathrm{K}_{4} \mathrm{P}_{1}$, kadar sukrosa tertinggi diperoleh pada kombinasi perlakuan $\mathrm{K}_{4} \mathrm{P}_{2}$. Sedangkan KKK terendah diperoleh pada perlakuan $\mathrm{K}_{1} \mathrm{P}_{0}$, sukrosa dan FA terendah diperoleh pada perlakuan $\mathrm{K}_{5} \mathrm{P}_{0}$, tiol terendah diperoleh pada perlakuan $\mathrm{K}_{2} \mathrm{P}_{1}$. Respon tanaman terhadap stimulasi bergantung pada kadar sukrosa lateks. Makin tinggi kadar sukrosanya, semakin tinggi intensitas stimulasi dapat dilakukan. Di samping itu tanaman lebih tahan terhadap stress akibat stimulasi (Jacob \& Prevot, 1992; Jacob, 1998; Gohet, 2008). 
Tabel 4. Uji beda rataan produksi dan karakter fisiologi lateks pada interaksi perlakuan klon dan paklobutrazol pada umur 54 bulan

Table 4. Mean different test of latex yield per tree and physiological characters of latex on the interaction by clone and paclobutrazol treatment at the age of 54 months

\begin{tabular}{|c|c|c|c|c|c|c|c|c|}
\hline \multirow[b]{2}{*}{$\begin{array}{l}\text { Klon } \\
\text { Clone } \\
(\mathrm{K})\end{array}$} & \multirow[b]{2}{*}{$\begin{array}{l}\text { Paklobutrazol } \\
\text { Paclobutrazol } \\
\text { (P) }\end{array}$} & \multicolumn{7}{|c|}{$\begin{array}{l}\text { Produksi dan karakter fisiologi lateks } \\
\text { Latex yield and latex physiological parameters }\end{array}$} \\
\hline & & $\begin{array}{l}\text { Produksi } \\
\text { lateks } \\
(\mathrm{g} / \mathrm{p} / \mathrm{s}) \\
\text { Latex yield } \\
(\mathrm{g} / \mathrm{t} / \mathrm{t})\end{array}$ & $\begin{array}{l}\mathrm{KKK} \\
D R C \\
(\%)\end{array}$ & $\begin{array}{l}\text { Sukrosa } \\
\text { Sucrose } \\
\text { (mM) }\end{array}$ & $\begin{array}{c}\text { FA } \\
P i \\
(m M)\end{array}$ & $\begin{array}{l}\text { Tiol } \\
\text { Thiol } \\
(m M)\end{array}$ & $\mathrm{pH}$ & $\begin{array}{l}\text { IP } \\
P I \\
(\%)\end{array}$ \\
\hline \multirow[b]{2}{*}{$\mathrm{K}_{1}=\mathrm{PB} 260$} & $\mathrm{P}_{0}=(0)$ & $14,12 \mathrm{de}$ & $32,98 \mathrm{~h}$ & $3,72 \mathrm{fg}$ & $3,63 \mathrm{de}$ & $0,34 \mathrm{bc}$ & $6,77 \mathrm{c}$ & $22,32 \mathrm{~g}$ \\
\hline & $\begin{array}{l}\mathrm{P}_{1}=(500 \mathrm{ppm}) \\
\mathrm{P}_{2}=(500 \mathrm{ppm}\end{array}$ & $\begin{array}{r}13,98 \mathrm{def} \\
18,42 \mathrm{c}\end{array}$ & $\begin{array}{l}34,73 \mathrm{def} \\
36,10 \mathrm{abc}\end{array}$ & $\begin{array}{r}3,82 \text { efg } \\
3,71 \text { fg }\end{array}$ & $\begin{array}{r}3,39 \text { efg } \\
3,84 \mathrm{~d}\end{array}$ & $\begin{array}{r}0,33 \mathrm{~cd} \\
0,30 \mathrm{fg}\end{array}$ & $\begin{array}{r}6,83 \mathrm{bc} \\
6,78 \mathrm{c}\end{array}$ & $\begin{array}{l}22,94 \mathrm{~g} \\
20,74 \mathrm{~h}\end{array}$ \\
\hline $\mathrm{K}_{2}=\mathrm{PB} 330$ & $\begin{array}{l}\mathrm{P}_{0}=(0) \\
\mathrm{P}_{1}=(500 \mathrm{ppm}) \\
\mathrm{P}_{2}=(500 \mathrm{ppm})\end{array}$ & $\begin{array}{c}12,53 \mathrm{gh} \\
13,69 \mathrm{cfg} \\
12,39 \mathrm{gh}\end{array}$ & $\begin{array}{c}33,40 \mathrm{gh} \\
34,95 \mathrm{de} \\
34,34 \mathrm{ef}\end{array}$ & $\begin{array}{r}4,13 \mathrm{c} \\
3,95 \mathrm{ef} \\
3,79 \mathrm{efg}\end{array}$ & $\begin{array}{r}3,47 \mathrm{ef} \\
3,16 \mathrm{gh} \\
3,25 \mathrm{fgh}\end{array}$ & $\begin{array}{r}0,32 \mathrm{de} \\
0,29 \mathrm{~g} \\
0,31 \mathrm{ef}\end{array}$ & $\begin{array}{r}6,83 \mathrm{bc} \\
6,88 \mathrm{~b} \\
6,67 \mathrm{~d}\end{array}$ & $\begin{array}{r}33,17 \mathrm{a} \\
29,40 \mathrm{de} \\
31,35 \mathrm{~b}\end{array}$ \\
\hline $\mathrm{K}_{3}=\mathrm{PB} 340$ & $\begin{array}{l}\mathrm{P}_{0}=(0) \\
\mathrm{P}_{1}=(500 \mathrm{ppm}) \\
\mathrm{P}_{2}=(500 \mathrm{ppm}\end{array}$ & $\begin{array}{l}22,81 \mathrm{a} \\
20,88 \mathrm{~b} \\
18,20 \mathrm{c}\end{array}$ & $\begin{array}{r}33,09 \mathrm{~h} \\
33,97 \mathrm{fg} \\
33,40 \mathrm{gh}\end{array}$ & $\begin{array}{l}5,90 \mathrm{c} \\
5,34 \mathrm{~d} \\
5,11 \mathrm{~d}\end{array}$ & $\begin{array}{r}4,33 \mathrm{c} \\
4,70 \mathrm{ab} \\
4,38 \mathrm{c}\end{array}$ & $\begin{array}{l}0,30 \mathrm{fg} \\
0,31 \mathrm{ef} \\
0,29 \mathrm{~g}\end{array}$ & $\begin{array}{l}7,02 \mathrm{a} \\
7,00 \mathrm{a} \\
7,03 \mathrm{a}\end{array}$ & $\begin{array}{r}19,63 \mathrm{hi} \\
19,70 \mathrm{hi} \\
18,71 \mathrm{i}\end{array}$ \\
\hline $\mathrm{K}_{4}=\mathrm{IRR} 107$ & $\begin{array}{l}\mathrm{P}_{0}=(0) \\
\mathrm{P}_{1}=(500 \mathrm{ppm}) \\
\mathrm{P}_{2}=(500 \mathrm{ppm})\end{array}$ & $\begin{array}{r}15,23 \mathrm{~d} \\
21,96 \mathrm{ab} \\
19,09 \mathrm{c}\end{array}$ & $\begin{array}{r}36,29 \mathrm{ab} \\
36,47 \mathrm{a} \\
36,00 \mathrm{abc}\end{array}$ & $\begin{array}{r}6,91 \mathrm{ab} \\
6,65 \mathrm{~b} \\
7,21 \mathrm{a}\end{array}$ & $\begin{array}{r}4,56 \mathrm{bc} \\
4,92 \mathrm{a} \\
4,92 \mathrm{a}\end{array}$ & $\begin{array}{l}0,37 \mathrm{a} \\
0,38 \mathrm{a} \\
0,35 \mathrm{~b}\end{array}$ & $\begin{array}{l}7,02 \mathrm{a} \\
6,89 \mathrm{~b} \\
6,89 \mathrm{~b}\end{array}$ & $\begin{array}{l}28,19 \mathrm{c} \\
22,95 \mathrm{~g} \\
24,71 \mathrm{f}\end{array}$ \\
\hline $\mathrm{K}_{5}=\mathrm{IRR} 5$ & $\begin{array}{l}\mathrm{P}_{0}=(0) \\
\mathrm{P}_{1}=(500 \mathrm{ppm}) \\
\mathrm{P}_{2}=(500 \mathrm{ppm}\end{array}$ & $\begin{array}{r}12,67 \mathrm{fgh} \\
12,20 \mathrm{~h} \\
12,65 \mathrm{fgh}\end{array}$ & $\begin{array}{r}34,53 \mathrm{ef} \\
35,51 \mathrm{bcd} \\
35,48 \mathrm{~cd}\end{array}$ & $\begin{array}{r}3,46 \mathrm{~g} \\
3,49 \mathrm{~g} \\
3,95 \mathrm{ef}\end{array}$ & $\begin{array}{l}3,11 \mathrm{~h} \\
3,07 \mathrm{~h} \\
3,60 \mathrm{e}\end{array}$ & $\begin{array}{r}0,31 \mathrm{efg} \\
0,31 \mathrm{ef} \\
0,33 \mathrm{cde}\end{array}$ & $\begin{array}{r}6,88 \mathrm{~b} \\
6,82 \mathrm{bc} \\
6,76 \mathrm{c}\end{array}$ & $\begin{array}{r}31,11 \mathrm{bc} \\
29,65 \mathrm{cde} \\
29,95 \mathrm{bcd}\end{array}$ \\
\hline
\end{tabular}

Keterangan: Angka yang diikuti huruf kecil yang sama pada kolom yang sama, menunjukkan berbeda tidak nyata pada taraf $5 \%$ berdasarkan Uji DMRT.

Note: Figures followed by the same letter in the same column were not significantly different at 5\% level according to Duncan Multiple Range Test

Paklobutrazol pada batang dapat meningkatkan kadar karbohidrat berupa fruktosa, glukosa dan sukrosa pada jaringan kayu (Wang et al., 1986). Hal ini sesuai dengan hasil penelitian bahwa kadar sukrosa tertinggi terdapat pada klon IRR 107 yang diaplikasi $500 \mathrm{ppm}$ paklobutrazol melalui daun (Tabel 4). Hal ini sangat berguna untuk proses pembentukan lateks. Lateks dihasilkan dari asimilat hasil fotosintesis dalam bentuk sukrosa di translokasi dari daun melalui pembuluh tapis ke dalam pembuluh lateks (Chaidamsari, 1987; Chantuma et al., 2006).

Perbedaan antar klon menunjukkan perbedaan dalam tanggap masing-masing klon terhadap perlakuan yang diberikan. $\mathrm{Hal}$ ini adalah wajar, mengingat perbedaan genetik antar klon menyebabkan perbedaanperbedaan secara fisiologis. Hal yang sama telah dilaporkan pada penelitian sebelumnya. Templeton (1969) dan Sethuraj (1992) menyatakan bahwa pertumbuhan tanaman sangat kompetitif dengan produksi lateks. Namun besarnya kompetisi tersebut beragam antar klon. Pada umumnya makin tinggi peningkatan produksi semakin rendah perkembangan lilit batang, hal ini sesuai dengan hasil penelitian bahwa klon yang produksinya lebih tinggi terdapat pada klon PB 340 (Tabel 3), sedangkan untuk perkembangan lilit batang terbesar terdapat pada klon PB 330 (Tabel 1). Klon karet dengan kadar fosfat anorganik tinggi pada lateks yang dihasilkannya maka lebih terhambat pertumbuhannya. Hal ini disebabkan oleh distribusi asimilat lebih banyak ke arah produksi lateks. Penurunan lilit batang berkorelasi negatif dengan kadar sukrosa awal (Lacote, 2007). Hal ini diperkuat oleh hasil penelitian Kuswanhadi et al. (2009) yang mendapatkan bahwa setiap klon dapat dikelompokkan menjadi klon 
Tabel 5. Korelasi antar parameter pada masing-masing klon

Table 5. Correlations between parameters on each clone

\begin{tabular}{|c|c|c|c|c|}
\hline \multicolumn{5}{|c|}{$\begin{array}{c}\text { Klon karet } \\
\text { Rubber clone }\end{array}$} \\
\hline PB 260 & PB 330 & PB 340 & IRR 107 & IRR 5 \\
\hline $\begin{array}{l}\text { PLB=PTK } \\
\text { PDPL=PTK }\end{array}$ & PLB & $\mathrm{PTK}=-\mathrm{PTT}$ & $\mathrm{PTK}=-\mathrm{PTT}$ & $\mathrm{PTK}=-\mathrm{PTT}$ \\
\hline PDPL=PJPL & $\mathrm{IP}=-\mathrm{PLB}$ & $\mathrm{PLB}=\mathrm{PTK}$ & $\mathrm{PLB}=\mathrm{PTK}$ & $\mathrm{PLB}=\mathrm{PTK}$ \\
\hline $\begin{array}{l}\text { KKK=PTK } \\
=\mathrm{PLB}\end{array}$ & $\begin{array}{l}\mathrm{KKK}=\mathrm{PLB}= \\
\mathrm{PDPL}=-\mathrm{IP}\end{array}$ & $\begin{array}{l}\mathrm{PDPL}=\mathrm{PTK}= \\
\mathrm{PLB}\end{array}$ & $\mathrm{KKK}=\mathrm{PLB}$ & $S=K K K$ \\
\hline $\begin{array}{l}\mathrm{S}=\mathrm{KKK}=\mathrm{FA} \\
\mathrm{FA}=\mathrm{PLB}\end{array}$ & $\mathrm{S}=-\mathrm{IP}=\mathrm{FA}$ & $S=-I P$ & $\mathrm{~T}=\mathrm{KKK}=\mathrm{FA}$ & $=\mathrm{S}$ sk \\
\hline $\begin{array}{l}\mathrm{T}=\mathrm{FA}=\mathrm{S} \\
\mathrm{S}=\mathrm{PLB}=\mathrm{KKK}\end{array}$ & $=\mathrm{FA}$ & $\mathrm{T}=\mathrm{FA}=\mathrm{S}$ & $\mathrm{T}=-\mathrm{IP}=\mathrm{FA} \quad \mathrm{sk}=\mathrm{S}$ & $\mathrm{P}=\mathrm{KKK}=\mathrm{S}$ \\
\hline $\begin{array}{l}\mathrm{P}=\mathrm{KKK}=\mathrm{FA} \\
=\mathrm{S}=\mathrm{T}\end{array}$ & $\begin{array}{l}\mathrm{T}=\mathrm{FA}=\mathrm{S} \\
\mathrm{P}=-\mathrm{IP}=\mathrm{FA}=\end{array}$ & $\mathrm{S}^{\mathrm{sk}}=\mathrm{T}$ & $\mathrm{P}=-\mathrm{IP}=\mathrm{FA} \quad \mathrm{sk}=\mathrm{S}$ & $=\mathrm{T}$ \\
\hline $\mathrm{P}=\mathrm{PLB}=\quad-\mathrm{IP}=$ & $\mathrm{KKK}=\mathrm{FA}=\mathrm{S}$ & & & \\
\hline
\end{tabular}

Keterangan (Remaks):

PLB : pertambahan lilit batang (girth accretion)

PTK : pertambahan tebal kulit (bark thickness accretion)

PDPL : pertambahan diameter pembuluh lateks (latex vessel diameter accretion)

PTT : pertambahan tinggi tanaman (plant height accretion)

PJPL : pertambahan jumlah pembuluh lateks (number oflatex vessel accretion)

IP : indeks penyumbatan (plugging index)

KKK : kadar karet kering (dry rubber content)

$\mathrm{T} \quad$ : tiol (Thiol)

FA : fosfat anorganik (inorganic phosphate)

S : sukrosa (sucrose)

$\mathrm{P} \quad$ : produksi (production)

sk : sangat kuat (very strong)

bermetabolisme tinggi, medium dan rendah berdasarkan kadar sukrosa dan posfat anorganik.

Hasil korelasi antara parameter pada masing-masing klon yang diamati dapat dilihat pada Tabel 5. Berdasarkan korelasi bahwa tujuan mempercepat matang sadap pada klon yang diinginkan dapat dikaitkan dengan parameter produksi dan karakter fisiologi lateks tertentu. Dari Tabel 5 dapat dilihat bahwa masing-masing klon memiliki hubungan korelasi yang berbeda antar parameter yang diamati. Sebagai contoh pada klon PB 260 untuk mempercepat matang sadap maka pertambahan lilit batang berhubungan dengan pertambahan tebal kulit, diameter pembuluh lateks dan jumlah pembuluh lateks. Hal ini juga akan mempengaruhi produksi. Produksi sangat berkaitan dengan kadar sukrosa dan tiol yang tinggi, akhirnya mempengaruhi kadar karet kering lateks, walaupun hubungan diantara parameter hanya sedang. 
Produksi lateks akan meningkat dengan meningkatnya kadar sukrosa lateks (pada klon PB 340 dan IRR 107) dan mempunyai hubungan korelasi yang sangat kuat, sedangkan dengan parameter lainnya mempunyai hubungan korelasi sedang. Tapi dengan parameter indeks penyumbatan mempunyai hubungan negatif. Hal ini berarti mempunyai hubungan tidak searah, dimana apabila produksi meningkat, maka indeks penyumbatan rendah atau kecil. Karena apabila indeks penyumbatan lateks tinggi maka laju aliran lateks akan cepat terhenti, sehingga produksi akan rendah atau menurun.

\section{KESIMPULAN}

Aplikasi paklobutrazol 500 ppm melalui tanah dapat menekan pertambahan tinggi tanaman karet, tetapi meningkatkan pertambahan lilit batang, jumlah pembuluh lateks, diameter pembuluh lateks dan karakter fisiologi lateks. Sehingga penggunaan paklobutrazol pada tanaman karet semasa TBM merupakan salah satu solusi untuk dapat mempercepat matang sadap di bawah umur 4 tahun. Untuk karakter fisiologi lateks yaitu parameter KKK, FA dan tiol kombinasi perlakuan terbaik terdapat pada klon IRR 107 yang diaplikasi paklobutrazol 500 ppm melalui tanah $\left(\mathrm{K}_{4} \mathrm{P}_{1}\right)$ dan untuk parameter sukrosa terdapat pada perlakuan paklobutrazol melalui daun $\left(\mathrm{K}_{4} \mathrm{P}_{2}\right)$

\section{DAFTAR PUSTAKA}

Anwar, C. (2006). Manajemen dan Teknologi Budidaya Karet. Pelatihan Tekno Ekonomi Agribisnis Karet. Medan, Indonesia: Pusat Penelitan Karet.

Aidi Daslin., Woelan, S., \& Suhendry, I. (2009). Bahan Tanaman Klon Karet Unggul. Medan, Indonesia: Balai Penelitian Sungei Putih, Pusat Penelitian Karet.

Aidi Daslin. (2014). Perkembangan penelitian klon karet unggul IRR Seri 100 sebagai penghasil lateks dan kayu. Warta Perkaretan, 33(1), 1-10. https://doi.org/10.22302/ppk.wp.v3 3i1.44
Bricard, P., \& Nicolas, D. (1989). Possibility of the use of physiologica parameters of latex in early selection. In d'Auzac, J., Jacob, J.L., \& Chrestin, H. Physiology of Rubber Tree. Florida, USA: Boca Raton CRC Press.

Coucaud, A.D., Brune 1, N ., Kongsawadworakul, P., Viboonjun,U., Lacinte, A., Julien,J.L., Chrestin, H., $\&$ Sakr, S. (2009). Sucrose importation into laticifers of Hevea brasiliensis, in relation to ethylene stimulation of latex production. Ann Bot. 104(4), 635-647. https://dx.doi.org/10.1093/aob/mcp 150

Chaidamsari, T. (1987). Ulasan tentang sifatsifat lateks dan hubungannya dengan jenis olahan karet. Warta Perkaretan, 6(2), 21-23.

Chantuma, P., Thanisawanyangkura, S., Kasemsap, P., Gohet, E., \& Thaler, P. (2006). Distribution pattern of latex sucrose content and concurrent metabolic activity at the trunk level with different tapping systems and in latex production bark of Hevea brasiliensis. Kasetsart Journal Natural Science, 40(3), 634-642.

Davis, T.D., Seffens, G.L., \& Sankhla, N. (1988). Triazol Plant Growth Regulator. Horticultural Reviews, 10, 64-89. https://doi.org/ 10.1002/978111806 0834.ch3

Dische, Z.M. (1962). Carbohydrate Chemical. New York, USA: Academic Press.

Do, K.T., Sivakumaran, S., \& Cho, W.K. (1996). Effects of tapping and intensive stimulation on yield, dryness incidence, and some physiological latex parameters of clone RRIM 600 . Journal of Natural Rubber Research, 11(3), 200-214. 
Gohet, E., Scomparin, C., Cavaloc, E., \& Balerin, Y. (2008). Influence of ethepon stimulation on latex physiological parameters and consequences on latex diagnosis implementation in rubber agroindustry. IRRDB Workshop on Latex Harvesting Technologies (11p.). Kuala Lumpur, Malaysia: IRRDB \& MRB.

Gomez, J.B. (1982). Anatomy of Hevea and its Influence on Latex Production. Kuala Lumpur, Malaysia: Malaysian Rubber Research Development Board.

ICI. (1986). Paclobutrazol Plant Growth Regulator for Fruit. Technical Data. UK: Plant Protection Devision Surrey.

Jacob, J.L., Prevot, C., Lacrotte, R., Clement, A., Gallois, R., Joet, T., PujadeRenaud, V., \& d'Auzac, J. (1989). Les mecanismes Biologiques de la Production de Cautchouc par Hevea brassiliensis. Plantations, Recherche, Developpement, 5(1), 5-17.

Jacob, J.L., \& Prevot, J.C. (1992). Metabolism of the Laticiferous System and its Biochemical Regulation. In. Sethuraj, M.R., \& Mathew, N.M. Natural Rubber: Biology, Cultivation and Technology. Netherland: Elsevier.

Kekwick, R.G.O. (1988). The in Vitro Biosynthesis of Hevea Latex Proteins. Colloque Hevea 88. Paris, France: CIRAD \& IRRDB.

Koryati, T. (1998). Pengaruh Aplikasi IAA, Kinetin dan Paklobutrazol pada Tanaman Karet Belum Menghasilkan Klon PB 260. [Tesis]. Medan, Indonesia: Program Pasca Sarjana Universitas Sumatera Utara.

Koryati, T., Napitupulu, J.A., Siregar, L.A.M., $\&$ Nisa, T.C (2015). Roles of growth regulator to shorten the immaturity period in some rubber clones. International Journal of Scientific and Technology Research, 4(5), 162-168.
Kuswanhadi., Sumarmadji., Karyudi., \& Siregar, T.H.S. (2009). Optimasi produksi klon karet melalui sistem eksploitasi berdasarkan metabolisme lateks. Prosiding Lokakarya Nasional Pemuliaan Tanaman Karet. Yogyakarta, Indonesia: Pusat Penelitian Karet.

Lacote, R. (2007). Some consideration concerning the yield potential of some clones Hevea brasiliensis. Proceedings of International Rubber Conference 2007. Siem Reap, Cambodia: IRRDB and CRRI.

Milford, G.F.J., Paardekooper, E.C., \& Ho, C.Y. (1969). Latex vessel plugging, its importance to yield and clonal behavior. J. Rubb. Res. Inst. Malaya, 21(3), 274-279.

Novalina., Jusuf, M., Wattimena, G.A., Suharsono., Sumarmadji., \& Aidi Daslin. (2008). Keragaan dan hubungan berbagai komponen hasil tanaman karet (Hevea brassiliensis Muell.Arg.) pada dua populasi persilangan PB 260 dan PN. Jurnal Agronomi Indonesia, 36(2), 153-160. https://doi.org/10.24831/jai.v36i2.2 0507

Sarkar, J., Annamalainathan, K. Krishnakumar, R., \& Jacob, J. (2015). Morpholigical changes in young plants of Hevea brasiliensis induced by Paklobutrazol. Rubber Science, 28(1), 22-30.

Sethuraj, M.R. (1992). Yield components in Hevea brassiliensis. Development in Crop Science, 23, 137-163. https: / / doi.org/ 10.1016/B978-0444-88329-2.50013-1

Sponsel, V.M. (1987). Gibberellin Biosynthesis and Metabolism. In Davies, P.J. Plant Hormones and Their Role in Plant Growth and Development. Netherland: Martinus Bijhoff Publisher. 
Sunariyo. (1996). Evaluasi fenotipe dan produksi awal tanaman karet populasi F1 hasil persilangan tahun 1992. [Skripsi]. Medan, Indonesia: Universitas Sumatera Utara.

Taussky, H.H., \& Shorr, E. (1953). A microcolometric methods for the determination of inorganic phosphorus. Journal of Biological Chemistry, 202(2), 675-678

Templeton, J.K. (1969). Partition of assimilates. J. Rub. Res. Inst. Malaya., 21, 259-273.

Wang, C.Y., Steffens, G.L., \& Faust, M. (1986). Effect of paclobutrazol on accumulation of carbohidrates in apple wood. Hort.Sci, 21(6), 14191421.

Wattimena, G.A. (1988). Zat Pengatur Tumbuh Tanaman. Bogor, Indonesia: Institut Pertanian Bogor.
West, C.A. (1990). Terpene and Byosinthesis Metabolism. In Denis, D.T., \& Turpin, D.H. Plant Physiology, Biochemestry and Molecular Biology. UK: Longman Sci \& Technical.

Woelan, S., Tistama, R., \& Aidi Daslin. (2007). Determinasi keragaman genetik hasil persilangan inter populasi berdasarkan karakteristik morfologi dan teknik RAPD. Jurnal Penelitian Karet, 25(1), 13-27.

Woelan, S., Sayurandi., \& Pasaribu, S.A. (2013). Karakter fisiologi, anatomi, pertumbuhan dan hasil lateks klon IRR Seri 300. Jurnal Penelitian Karet, 31(1), 1-12. https://doi.org/10.22302 /ppk.jpk.v31i1.128 
Lampiran 1. Rataan tinggi tanaman (m) pada pengamatan awal dan umur 46 bulan Appendix 1. Avarage of plant height $(\mathrm{m})$ at initial observation and at the age of 46 months

\begin{tabular}{|c|c|c|}
\hline \multirow[b]{2}{*}{$\begin{array}{l}\text { Perlakuan } \\
\text { Treatment }\end{array}$} & \multicolumn{2}{|c|}{$\begin{array}{c}\text { Tinggi tanaman pada umur } \\
\text { Plant height at age } \\
(\mathrm{m})\end{array}$} \\
\hline & $\begin{array}{c}28 \text { (Awal) } \\
\text { (bulan) } \\
\text { Initial } \\
\text { (months) }\end{array}$ & $\begin{array}{c}46 \text { (18 BSP) } \\
\text { (bulan) } \\
18 \text { months after } \\
\text { treatment } \\
\text { (months) }\end{array}$ \\
\hline $\mathrm{K}_{1} \mathrm{P}_{0}$ & 7,08 & 9,97 \\
\hline $\mathrm{K}_{1} \mathrm{P}_{1}$ & 7,18 & 8,96 \\
\hline $\mathrm{K}_{1} \mathrm{P}_{2}$ & 6,77 & 9,42 \\
\hline $\mathrm{K}_{2} \mathrm{P}_{0}$ & 6,20 & 10,01 \\
\hline $\mathrm{K}_{2} \mathrm{P}_{1}$ & 6,48 & 9,19 \\
\hline $\mathrm{K}_{2} \mathrm{P}_{2}$ & 6,34 & 9,70 \\
\hline $\mathrm{K}_{3} \mathrm{P}_{0}$ & 6,45 & 10,58 \\
\hline $\mathrm{K}_{3} \mathrm{P}_{1}$ & 6,75 & 8,88 \\
\hline $\mathrm{K}_{3} \mathrm{P}_{2}$ & 6,49 & 9,63 \\
\hline $\mathrm{K}_{4} \mathrm{P}_{0}$ & 6,68 & 10,76 \\
\hline $\mathrm{K}_{4} \mathrm{P}_{1}$ & 6,42 & 8,88 \\
\hline $\mathrm{K}_{4} \mathrm{P}_{2}$ & 6,31 & 9,29 \\
\hline $\mathrm{K}_{5} \mathrm{P}_{0}$ & 6,77 & 10,93 \\
\hline $\mathrm{K}_{5} \mathrm{P}_{1}$ & 6,77 & 9,18 \\
\hline $\mathrm{K}_{5} \mathrm{P}_{2}$ & 6,56 & 9,63 \\
\hline
\end{tabular}

Lampiran 2. Rataan lilit batang pada pengamatan awal dan umur 46 bulan Appendix 2. Avarage of girth at Initial observation and at the age of 46 months

\begin{tabular}{|c|c|c|}
\hline \multirow[b]{2}{*}{$\begin{array}{l}\text { Perlakuan } \\
\text { Treatment }\end{array}$} & \multicolumn{2}{|c|}{$\begin{array}{c}\text { Lilit batang pada umur } \\
\text { Girth at age } \\
(\mathrm{cm})\end{array}$} \\
\hline & $\begin{array}{c}28 \text { (Awal) } \\
\text { (bulan) } \\
\text { Initial } \\
\text { (months) }\end{array}$ & $\begin{array}{c}46(18 \mathrm{BSP}) \\
\text { (bulan) } \\
18 \text { months after } \\
\text { treatment } \\
\text { (months) }\end{array}$ \\
\hline $\mathrm{K}_{1} \mathrm{P}_{0}$ & 23,36 & 40,75 \\
\hline $\mathrm{K}_{1} \mathrm{P}_{1}$ & 23,30 & 45,40 \\
\hline $\mathrm{K}_{1} \mathrm{P}_{2}$ & 23,68 & 44,75 \\
\hline $\mathrm{K}_{2} \mathrm{P}_{0}$ & 23,74 & 40,40 \\
\hline $\mathrm{K}_{2} \mathrm{P}_{1}$ & 23,74 & 46,50 \\
\hline $\mathrm{K}_{2} \mathrm{P}_{2}$ & 23,68 & 47,40 \\
\hline $\mathrm{K}_{3} \mathrm{P}_{0}$ & 23,50 & 40,15 \\
\hline $\mathrm{K}_{3} \mathrm{P}_{1}$ & 23,29 & 46,10 \\
\hline $\mathrm{K}_{3} \mathrm{P}_{2}$ & 23,53 & 45,00 \\
\hline $\mathrm{K}_{4} \mathrm{P}_{0}$ & 23,57 & 40,20 \\
\hline $\mathrm{K}_{4}^{4} \mathrm{P}_{1}$ & 23,28 & 44,85 \\
\hline $\mathrm{K}_{4} \mathrm{P}_{2}$ & 23,77 & 45,25 \\
\hline $\mathrm{K}_{5} \mathrm{P}_{0}$ & 24,19 & 40,30 \\
\hline $\mathrm{K}_{5} \mathrm{P}_{1}$ & 23,89 & 46,50 \\
\hline $\mathrm{K}_{5} \mathrm{P}_{2}$ & 23,69 & 45,25 \\
\hline
\end{tabular}


Lampiran 3. Rangkuman rata-rata tebal kulit, jumlah pembuluh lateks dan diameter pembuluh lateks pada pengamatan awal dan umur 46 bulan

Appendix 3. Summarize bark thickness, number of latex vessel and diameter of latex vessel at initial observation and at the age of 46 months

\begin{tabular}{|c|c|c|c|c|c|c|}
\hline \multirow{3}{*}{$\begin{array}{l}\text { Perlakuan } \\
\text { Treatment }\end{array}$} & \multicolumn{2}{|c|}{$\begin{array}{c}\text { Tebal kulit } \\
\text { Bark thickness } \\
(\mathrm{mm})\end{array}$} & \multicolumn{2}{|c|}{$\begin{array}{l}\text { Jumlah pembuluh } \\
\text { lateks } \\
\text { Number of latex vessel }\end{array}$} & \multicolumn{2}{|c|}{$\begin{array}{c}\text { Diameter pembuluh lateks } \\
\text { Diameter of latex vessel } \\
(\mathrm{m} \mu)\end{array}$} \\
\hline & \multicolumn{6}{|c|}{$\begin{array}{l}\text { Pada umur } \\
\text { (bulan) } \\
\text { At the age of } \\
\text { (months) }\end{array}$} \\
\hline & 28 & 46 & 28 & 46 & 28 & 46 \\
\hline $\mathrm{K}_{1} \mathrm{P}_{0}$ & 3,00 & 5,01 & 2,50 & 3,50 & 12,88 & 24,38 \\
\hline $\mathrm{K}_{1} \mathrm{P}_{1}$ & 3,00 & 6,62 & 3,00 & 5,00 & 11,88 & 26,75 \\
\hline $\mathrm{K}_{1} \mathrm{P}_{2}$ & 3,10 & 6,24 & 2,00 & 5,00 & 11,25 & 26,32 \\
\hline $\mathrm{K}_{2} \mathrm{P}_{0}$ & 3,50 & 5,06 & 2,50 & 4,00 & 13,44 & 23,44 \\
\hline $\mathrm{K}_{2} \mathrm{P}_{1}$ & 3,50 & 6,30 & 2,00 & 6,00 & 11,88 & 25,00 \\
\hline $\mathrm{K}_{2} \mathrm{P}_{2}$ & 3,35 & 6,04 & 2,00 & 6,00 & 10,63 & 24,69 \\
\hline $\mathrm{K}_{3} \mathrm{P}_{0}$ & 3,25 & 4,76 & 2,50 & 4,00 & 14,07 & 24,69 \\
\hline $\mathrm{K}_{3} \mathrm{P}_{1}$ & 3,20 & 6,78 & 2,50 & 5,00 & 10,00 & 24,69 \\
\hline $\mathrm{K}_{3} \mathrm{P}_{2}$ & 3,25 & 6,57 & 3,00 & 5,00 & 12,19 & 24,69 \\
\hline $\mathrm{K}_{4} \mathrm{P}_{0}$ & 3,30 & 5,03 & 2,50 & 4,00 & 12,82 & 24,07 \\
\hline $\mathrm{K}_{4} \mathrm{P}_{1}$ & 3,45 & 6,48 & 2,50 & 6,00 & 11,88 & 25,32 \\
\hline $\mathrm{K}_{4} \mathrm{P}_{2}$ & 3,10 & 6,32 & 2,50 & 5,00 & 11,57 & 24,22 \\
\hline $\mathrm{K}_{5} \mathrm{P}_{0}$ & 3,45 & 4,94 & 2,50 & 5,00 & 13,13 & 24,38 \\
\hline $\mathrm{K}_{5} \mathrm{P}_{1}$ & 3,25 & 6,37 & 3,50 & 5,00 & 11,88 & 24,38 \\
\hline $\mathrm{K}_{5} \mathrm{P}_{2}$ & 3,10 & 6,12 & 2,50 & 5,50 & 10,63 & 23,44 \\
\hline
\end{tabular}

